Article

\title{
Effect of Co-Inoculation with Pichia fermentans and Pediococcus acidilactici on Metabolite Produced During Fermentation and Volatile Composition of Coffee Beans
}

\author{
Alexander da Silva Vale ${ }^{1}$, Gilberto Vinícius de Melo Pereira ${ }^{1, *}$, Dão Pedro de Carvalho Neto ${ }^{1}(\mathbb{D}$, \\ Cristine Rodrigues ${ }^{1}$, Maria Giovana B. Pagnoncelli ${ }^{2}$ and Carlos Ricardo Soccol ${ }^{1 \text {,* }}$ \\ 1 Department of Bioprocess Engineering and Biotechnology, Federal University of Paraná (UFPR), \\ 19011Curitiba, Paraná 81531-980, Brazil \\ 2 Departament of Chemistry and Biology, Federal University of Technology-Paraná (UTFPR), \\ Curitiba PR 80230-901, Brazil \\ * Correspondence: gilbertovinicius@gmail.com (G.V.d.M.P.); soccol@ufpr.br (C.R.S.); \\ Tel.: +55-41-33-613-697 (G.V.d.M.P.); +55-41-33-613-191 (C.R.S.)
}

Received: 2 July 2019; Accepted: 19 July 2019; Published: 22 July 2019

\begin{abstract}
Removal of the mucilage layer of coffee fruits by a fermentation process has became an interesting strategy to improve coffee quality, which is able to assist the formation of flavored molecules. In this study, four sets of inoculation protocols were evaluated using ripe and immature coffee fruits, respectively, including (i) pure culture fermentation with Pichia fermentans, (ii) pure culture fermentation with Pediococcus acidilactici, (ii) combined fermentation with P. fermentans and $P$. acidilactici, and (iv) spontaneous, non-inoculated control. The initial pulp sugar concentration of ripe coffee fruits ( 0.57 and $1.13 \mathrm{~g} / \mathrm{L}$ glucose and fructose content, respectively) was significantly higher than immature coffee pulp ( 0.13 and $0.26 \mathrm{~g} / \mathrm{L}$ glucose and fructose content, respectively). Combined inoculation with P. fermentans and P. acidilactici of ripe coffee beans increased pulp sugar consumption and production of metabolites (lactic acid, ethanol, and ethyl acetate), evidencing a positive synergic interaction between these two microbial groups. On the other hand, when immature coffee fruits were used, only pure culture inoculation with P. fermentans was able to improve metabolite formation during fermentation, while combined treatment showed no significant effect. Altogether, 30 volatile compounds were identified and semi-quantified with HS- solid phase microextraction (SPME)-gas chromatography coupled to mass spectrophotometry (GC/MS) in fermented coffee beans. In comparison with pure cultures and spontaneous process, combined treatment prominently enhanced the aroma complexity of ripe coffee beans, with a sharp increase in benzeneacetaldehyde, 2-heptanol, and benzylalcohol. Consistent with the monitoring of the fermentation process, only P. fermentans treatment was able to impact the volatile composition of immature coffee beans. The major impacted compounds were 2-hexanol, nonanal, and D-limonene. In summary, this study demonstrated the great potential of the combined use of yeast and lactic acid bacteria to improve fermentation efficiency and to positively influence the chemical composition of coffee beans. Further studies are still required to investigate the mechanisms of synergism between these two microbial groups during the fermentation process and influence the sensory properties of coffee products.
\end{abstract}

Keywords: coffee processing; coffee fermentation; starter culture; coffee beverage; yeast

\section{Introduction}

Coffee plants are cultivated in more than 80 countries around the world, providing raw materials for a global industry valued at an excess of 10 billion US\$ [1]. Production conditions and post-harvest 
operations, such as fruit harvesting, depulping, drying, and storage, have a direct impact on the quality of coffee products. Fruit harvesting is the first step in postharvest coffee processing. The heterogeneous development of coffee fruits leads to a simultaneous presence of different maturation stages in the same coffee tree, namely: (i) Green (immature) coffee fruits, presenting incomplete endosperm development and low reducing sugars content in the mucilaginous layer; (ii) cherry (ripe) fruits, presenting mucilage rich in reducing sugars, complete development of the endosperm and red or yellow exocarp color; and (iii) raisin (overripe), which are fruits showing the initial characteristics of the senescence cycle with metabolic pathway deviation for the catabolism of the nutrients accumulated in the beans [2]. In Brazil, the largest coffee producer in the world, it is estimated that $31 \%$ of the coffee fruits are harvested in the immature stage [3]. Immature coffee beans have a high content of chlorogenic acids (caffeine, trigonelline) and lower sugar content due to incomplete cycle of maturation, attributing astringency and depreciating the quality of coffee products $[4,5]$.

After harvesting, coffee processing must begin as quickly as possible to prevent fruit spoilage by unfavorable fermentation or mold formation [6,7]. The outer layers of the coffee fruit (skin and pulp) are easily removed, while the mucilage, parchment, and silver skin are firmly attached to the beans [8]. The way that coffee growers use to remove the mucilage layer attached to the fruits classifies coffee in the international market: 'Natural coffee', where mucilage is removed by a simple method of sun-drying, known as dry processing; 'washed coffee', produced from coffee beans that undergo a relatively complex series of steps, including depulping, fermentation, and sun-drying known as wet processing; and "pulped natural coffee", which the fruits are mechanically husked and the mucilage is removed by a sun-drying process, known as semi-dry processing [9].

In the wet processing, coffee beans are submitted to underwater tank fermentation for mucilage breakdown and removal. The sugars present in the mucilage support microbial, especially yeasts and lactic acid bacteria [10]. Recent studies have been dedicated to the use of yeast and lactic acid bacteria (LAB) as pure starter cultures in post-harvest processing, in order to reduce the time required for fermentation and modulate the chemical and sensory characteristics of coffee beans [11-14]. Among the selected microorganisms, it is possible to highlight the yeast Pichia fermentans YC5.2 and the lactic acid bacteria Pediococcus acidilactici LPBC161, which are cultures with characteristics of efficient consumption of coffee pulp-sugars and adaptability to the stress factors of coffee processing [15,16]. Despite that the use of pure cultures offers advantages, recent studies in wine, meat, and dairy fermentations demonstrate that mixed starters are able to improve the sensorial and safety proprieties of the final product $[17,18]$. In this regard, the aim of this study was to evaluate the effects of co-inoculation with Pichia fermentans YC5.2 and Pediococcus acidilactici LPBC161 on metabolites produced during fermentation and the volatile composition of coffee beans.

\section{Material and Methods}

\subsection{Microorganism and Inoculum Preparation}

The selected yeast (Pichia fermentans YC5.2) and lactic acid bacteria (Pediococcus acidilactici LPBC161) strains used in this study were previously isolated and selected from spontaneous coffee fermentations, as detailed in Muynarsk et al. [15] and Pereira et al. [16]. The P. fermentans YC5.2 and P. acidilactici LPBC161 were reactivated in MRS (Merck Millipore, Burlington, MA) and YEPG broth (Himedia, Marg, India), respectively, at $28^{\circ} \mathrm{C}$ during $24 \mathrm{~h}$. Each microorganism was then grown up to a concentration of $10^{9} \mathrm{CFU} / \mathrm{mL}$. To reach this concentration, P. acidilactici LPBC161 was cultivated in Erlenmeyer containing $4 \mathrm{~L}$ of sugar cane molasses $3 \%(\mathrm{w} / \mathrm{v})$ medium, enriched with yeast extract $0.5 \%(\mathrm{w} / \mathrm{v})$, ammonium citrate $0.5 \%(\mathrm{w} / \mathrm{v})$, ammonium phosphate $0.5 \%(\mathrm{w} / \mathrm{v})$, sodium acetate $0.5 \%(\mathrm{w} / \mathrm{v})$, Tween 80 $0.1 \%(\mathrm{v} / \mathrm{v})$, and manganese sulfate $0.005 \%(\mathrm{w} / \mathrm{v})$ [19], and P. fermentans YC5.2 was grown in Erlenmeyer containing $4 \mathrm{~L}$ of sugar cane molasses $3 \%(\mathrm{w} / \mathrm{v})$ medium enriched with yeast extract $0.5 \%(\mathrm{w} / \mathrm{v})$. After incubation, the yeast and lactic acid bacteria (LAB) cells were separated from the medium by centrifugation at $5000 \times g$ during $5 \mathrm{~min}$, washed twice with sterile saline-peptone solution $(0.1 \% \mathrm{w} / \mathrm{v}]$ 
bacteriological peptone (Himedia), $0.8 \%$ (w/v; $\mathrm{NaCl}$ (Merck)), and resuspended in sterile saline solution $(0.9 \%(\mathrm{w} / \mathrm{v}) \mathrm{NaCl})$.

\subsection{Farm Experiments}

The field experiments were conducted at the Fazenda Baobá $\left(21^{\circ} 42^{\prime} 42.8^{\prime \prime} \mathrm{S}, 46^{\circ} 49^{\prime} 42.2^{\prime \prime}\right.$ W; $1400 \mathrm{~m}$ above sea level) situated in São Sebastião da Grama, São Paulo state, Brazil. Ripe and immature coffee fruits $(10 \mathrm{~kg})$ were, respectively, deposited in 20-L plastic buckets with $5 \mathrm{~L}$ of water. Four sets of inoculation protocols were performed in triplicate: (i) Pure culture fermentation with P. fermentans, (ii) pure culture fermentation with P. acidilactici, (ii) combined fermentation with P. fermentans and P. acidilactici, and (iv) spontaneous, non-inoculated control. Prior to inoculation, yeast and LAB cells were counted by a Thoma hemocytometer chamber using methylene blue dye as a marker of cell viability. Then, appropriate amounts of inoculum were used to reach an initial cell population of about $7 \log \mathrm{CFU} / \mathrm{mL}$. At the end of fermentation, coffee beans were sun dried until the value of $12 \%$ of moisture was reached.

\subsection{Sampling and $p H$ Measurement}

Samples $(50 \mathrm{~mL})$ of the liquid fraction of the fermenting coffee pulp were collected in triplicate at intervals of $12 \mathrm{~h}$ to monitor sugars consumption and organic acids, ethanol, and volatile compounds production. At each sampling point, the $\mathrm{pH}$ was measured using a digital $\mathrm{pH}$ meter (Requipal, Curitiba, Brazil).

\subsection{HPLC Analysis of Fermenting Coffee Pulp}

The concentration of reducing sugars (glucose and fructose), organic acids (citric, succinic, lactic, acetic, and propionic acids), and ethanol in coffee pulp (liquid fraction) was determined in intervals of $12 \mathrm{~h}$. Aliquots of $2 \mathrm{~mL}$ were centrifuged at $6000 \times \mathrm{g}$ for $15 \mathrm{~min}$ and filtered through $0.22 \mu \mathrm{m}$ pore size filter (Millipore Corp., Billerica, MA, USA). Analysis parameters were performed according to Carvalho Neto et al. [20]. The filtered samples were injected into high-performance liquid chromatograph (HPLC) system equipped with an Aminex HPX $87 \mathrm{H}$ column $(300 \times 7.8 \mathrm{~mm}$; Bio-Rad, Richmond, CA, USA) and a refractive index (RI) detector (HPG1362A; Hewlett-Packard Company, Palo Alto, CA, USA). The column was eluted in an isocratic mode with a mobile phase of $5 \mathrm{mM} \mathrm{H} 2 \mathrm{SO} 4$ at $60{ }^{\circ} \mathrm{C}$ and a flow rate of $0.6 \mathrm{~mL} / \mathrm{min}$.

\subsection{GC Analysis of Fermenting Coffee Pulp}

The formation of major volatile compounds was determined in intervals of $12 \mathrm{~h}$ by gas chromatography. For sample preparation, aliquots $(4 \mathrm{~mL})$ from the liquid fraction of the fermenting coffee pulp were placed in $20 \mathrm{~mL}$ hermetically sealed flasks containing $\mathrm{NaCl} 5 \%(\mathrm{w} / \mathrm{v})$, followed by heating during $10 \mathrm{~min}$ at $60^{\circ} \mathrm{C}$. The headspace was then collected using a glass syringe (Hamilton, Bonaduz, Switzerland) and injected into a gas chromatograph (model 17A; Shimadzu, Kyoto, Japan) equipped with a flame ionization detector at $230^{\circ} \mathrm{C}$. The operation conditions were as follows: A $30 \mathrm{~m}$ $\times 0.32 \mathrm{~mm}$ HP- 5 capillary column, column temperature of 40 to $150{ }^{\circ} \mathrm{C}$ at a rate of $20^{\circ} \mathrm{C} / \mathrm{min}$ [13]. A standard curve was constructed using authentic analytical standards purchased from Sigma and concentration of the compounds was expressed as $\mu \mathrm{mol} / \mathrm{L}$ of headspace

\subsection{GC/MS Analysis of Fermented Coffee Beans}

The volatile aroma compound composition of spontaneous and inoculated coffee beans was determined by gas chromatography coupled to mass spectrophotometry (GC-MS) according to Carvalho Neto et al. [20]. The extraction of volatile compounds from the beans samples ( $2 \mathrm{~g})$ was performed using a headspace vial coupled to a solid phase microextraction (SPME) fiber DVB/CAR/PDMS fiber (Supelco Co., Bellefonte, PA, USA). The flasks were heated at $70{ }^{\circ} \mathrm{C}$ for $10 \mathrm{~min}$ without agitation, 
followed by $15 \mathrm{~min}$ of exposition of the fiber in a COMBI-PAL system. The compounds were desorbed into the gas chromatograph injection system gas phase (CGMS-gun TQ Series 8040 and 2010 Plus GC-MS; Shimadzu, Tokyo, Japan) at $260^{\circ} \mathrm{C}$. The column oven temperature was maintained at $60^{\circ} \mathrm{C}$ during $10 \mathrm{~min}$, followed by two heating ramps of 4 and $10^{\circ} \mathrm{C} / \mathrm{min}$ until reaching the temperatures of 100 and $200{ }^{\circ} \mathrm{C}$, respectively. The compounds were separated on a column $95 \%$ PDMS/5\% PHENYL (30 $\mathrm{m} \times 0.25 \mathrm{~mm} \times 0.25 \mathrm{~mm}$ film thickness). The GC was equipped with an HP 5972 mass selective detector (Hewlett Packard, Palo Alto, CA, USA). Helium was used as carrier gas at a rate of $1.0 \mathrm{~mL} / \mathrm{min}$. Mass spectra were obtained by electron impact at $70 \mathrm{eV}$ and a start and end mass-to-charge ratio $(\mathrm{m} / \mathrm{z})$ of 30 and 200, respectively. The compounds were identified by comparison to the mass spectra from library databases (Nist'98 and Wiley7N).

\subsection{Statistical Analysis}

The data obtained of target metabolite analysis were analyzed by post-hoc comparison of means by Duncan's test and a principal component analysis (PCA). Statistical analyses were performed using the SAS program (Statistical Analysis System Cary, NC, USA). Level of significance was established in a two-sided $p$-value $<0.05$.

\section{Results and Discussion}

\subsection{Field Experiment}

The use of mixed fermentation instead a single culture is a practice widely applied in winemaking in order to improve the aroma complexity or mouth-feel of wines [21,22]. It offers a number of advantages over conventional single-culture fermentations, including higher microbial growth rate and metabolite yield, better utilization of the substrate, and complex formation of aromatic compounds [23]. This work represents the first study on a mixed culture in the coffee beans fermentation process. We experimentally tested the impact of the combination of two selected cultures (P. fermentans YC5.2 and P. acidilactici LPBC161) in terms of the fermentation efficiency and volatile composition of coffee beans. The experiments were performed with individual and combined inoculations in ripe and immature coffee beans, compared to a spontaneous process. The changes in major non-volatiles (sugars, organic acids, and ethanol) and volatiles metabolites were quantified in the course of the fermentation time. The initial pulp sugar concentration of ripe coffee fruits $(0.57$ and $1.13 \mathrm{~g} / \mathrm{L}$ glucose and fructose content, respectively) was significantly higher than immature coffee pulp ( 0.13 and $0.26 \mathrm{~g} / \mathrm{L}$ glucose and fructose content, respectively; Figure 1). The low levels of sugars in the case of immature coffee are the consequence of incomplete maturation cycle fruits [24]. In all fermentation processes, the sugar concentration showed an increase during the initial $12 \mathrm{~h}$. This phenomenon can be associated with the hydrolysis of pectin, cellulose, sucrose, and other coffee pulp complexes carbohydrates, into monomers of glucose and fructose [25,26]. After this increase, both glucose and fructose were partially consumed, resulting in a residual concentration of around 0.37 and $1.51 \mathrm{~g} / \mathrm{L}$ (ripe coffee pulp) and 0.19 and $0.74 \mathrm{~g} / \mathrm{L}$ (immature coffee pulp) of glucose and fructose, respectively. Residual pulp sugars are generally observed after the coffee fermentation process, mainly associated with the short fermentation cycle $[14,27,28]$. However, fructose consumption was more efficient in the treatments that the yeast was used (i.e., P. fermentans-pure culture and combined treatment with P. fermentans and P. acidilactici) than P. acidilactici pure culture and spontaneous assay (Figure 1). The yeast's ability to withstand stress tolerance factors and the production of pectinolytic enzymes confer advantages in comparison to lactic acid bacteria $[16,29]$. In addition, the low availability of initially willing nutrients in immature coffee pulp [24] may have restricted the development of $P$. acidilactici, showing poor sugar consumption (Figure 1B). Lactic acid bacteria are further distinguished by their limited biosynthetic abilities, being unable to synthesize multiple cofactors, vitamins, purines, pyrimidines, and other nutrients [30]. 


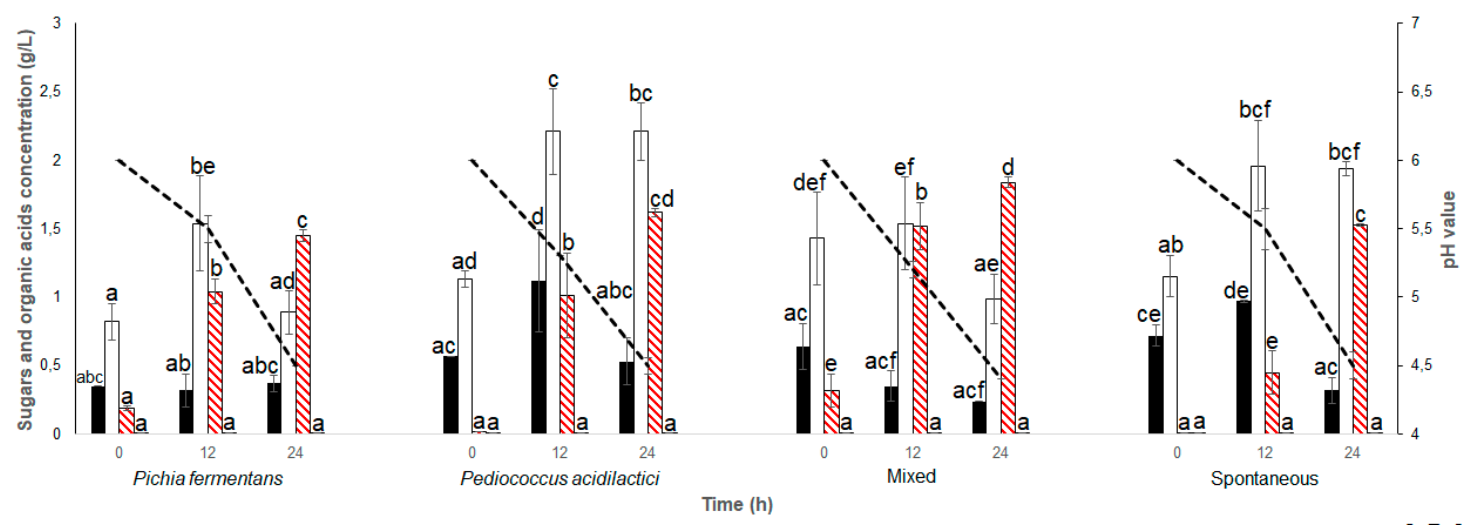

Ripe coffee

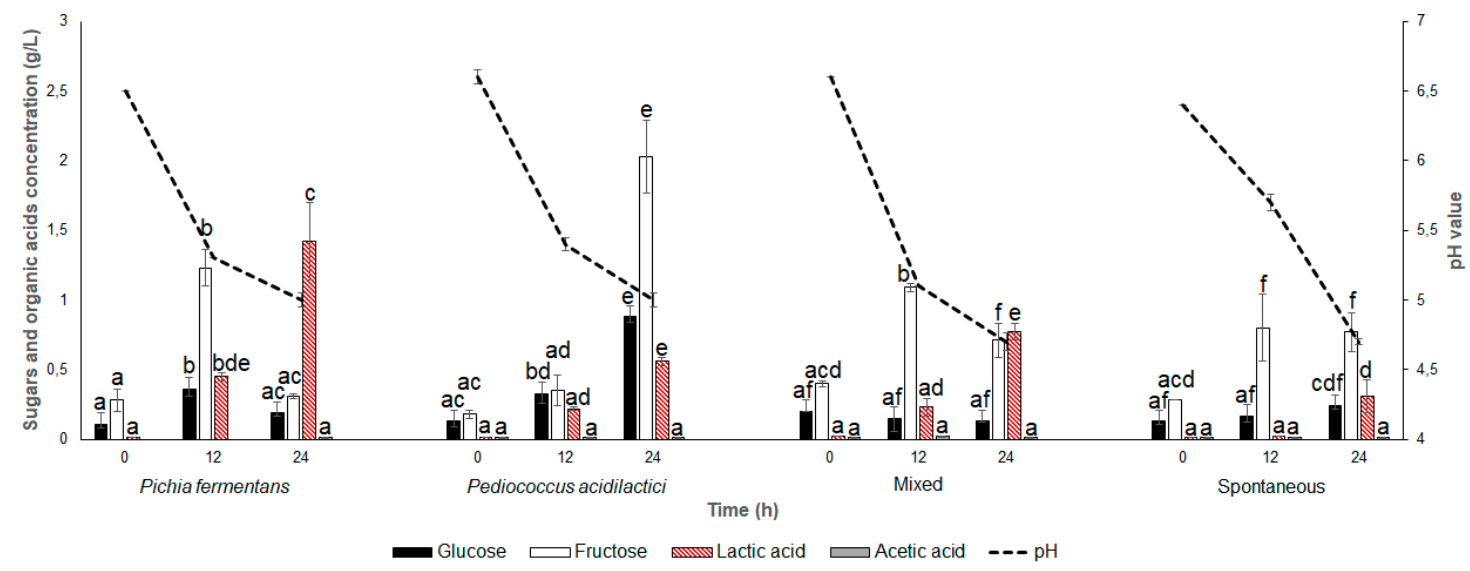

Immature coffee

Figure 1. Pulp sugar consumption, organic acid production, and $\mathrm{pH}$ monitoring of inoculated (pure culture with Pichia fermentans, pure culture with Pediococcus acidilactici, and combined fermentation with P. fermentans and P. acidilactici) and spontaneous fermentation of ripe (A) and immature (B) coffee fruits. The significance of the results was assessed using an ANOVA with Duncan's post-hoc test at $p<0.05$. Different lowercase letters $(\mathrm{a}, \mathrm{b}, \mathrm{c}, \mathrm{d}, \mathrm{e}, \mathrm{f})$ indicate significant differences within the same process (ripe and immature coffee beans) over fermentation time.

Lactic acid showed a significant increase through fermentative processes, reaching maximum concentration of $\geq 1.45$ and $\geq 0.53 \mathrm{~g} / \mathrm{L}$ in the ripe and immature treatments, respectively (Figure 1 ). Basal concentrations of acetic acid $(\leq 0.01 \mathrm{~g} / \mathrm{L})$ were detected in all the processes, which can be associated with yeast metabolism or the heterofermentative nature of P. acidilactici [31,32]. Overfermentation acids, such as propionic and butyric acids, were not detected in both ripe and immature treatments. In this sense, the acidification of fermenting coffee pulp can be attributed mainly to lactic acid content. As expected, while the lactic acid concentration increased, the $\mathrm{pH}$ decreased progressively during all fermentation processes (Figure 1). Lactic acid is an important end-metabolite associated with coffee fermentation, which assists in the coffee-pulp acidification process without interference in the final product (Figure 1). The $\mathrm{pH}$ monitoring is a crucial parameter, since $\mathrm{pH}$ values below 4.5 are used as to indicate the end of the coffee fermentation process [33-35]. In immature coffee treatments, a pH higher than 4.5 was reported, which may be attributed to the insufficient development of $P$. acidilactici.

Ethanol and ethyl acetate were the major volatile compounds detected during fermentation processes (Figure 2). Interestingly, combined inoculations with P. acidilactici and P. fermentans resulted in a significant increase in the production of these metabolites when compared to pure cultures and a spontaneous process. The higher values of ethanol $(27.04$ and $14.8 \mu \mathrm{mol} / \mathrm{L})$ and ethyl acetate $(1.63$ and $1.21 \mu \mathrm{mol} / \mathrm{L}$ ) were reached after $24 \mathrm{~h}$ of ripe and immature combined fermentations, respectively. 
This agrees with the findings of Sun et al. [36] and Cañas et al. [37] that demonstrated an increase of ethyl- and acetate esters as a result of the co-inoculation of LAB and yeasts in wine fermentation. The significant sugar consumption and lactic acid, ethyl acetate, and ethanol production in treatments with combined inoculations indicated an ecological interaction between these two microbial groups. The complex nature of this interaction is highlighted by the observations that (i)the autolysis of yeasts release nutrients, such as amino acids, polysaccharides and riboflavin, favorable for bacterial growth, and that (ii) the acidification of the fermentation media by LAB creates a prone environment for yeast development $[9,38,39]$. These positive interactions have been shown to promote desired sensory attributes in wine, sourdough, and yogurt. However, information about these mechanisms in coffee fermentation is scarce [40].

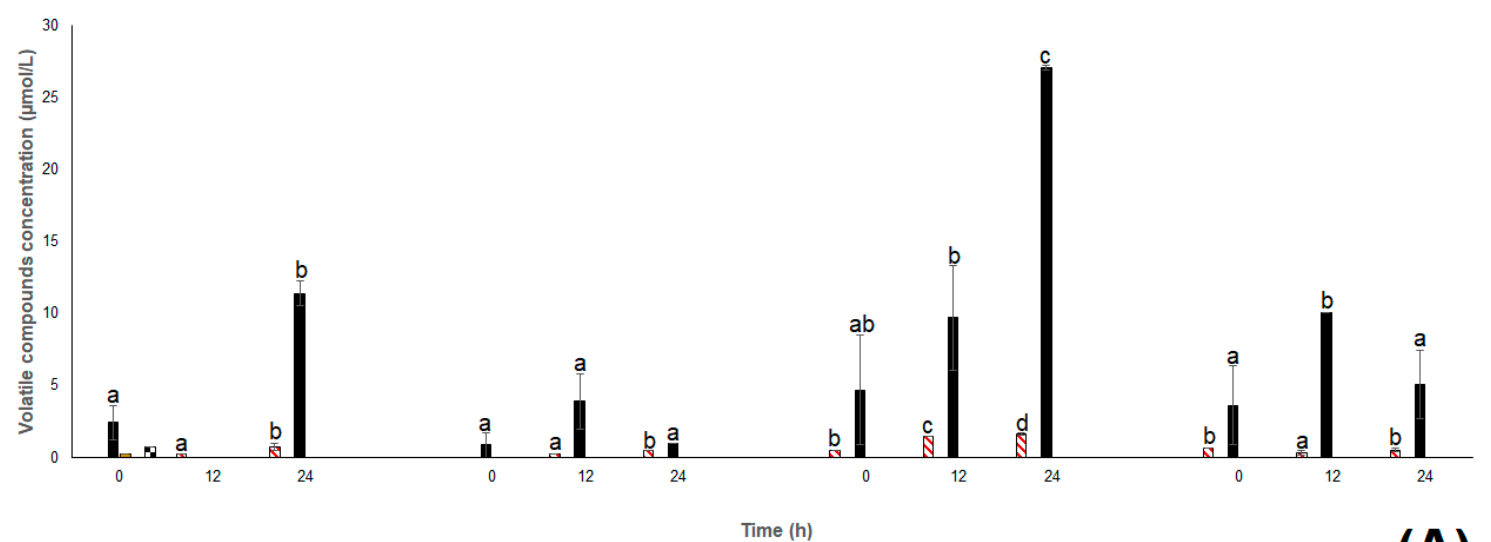

Ripe coffee

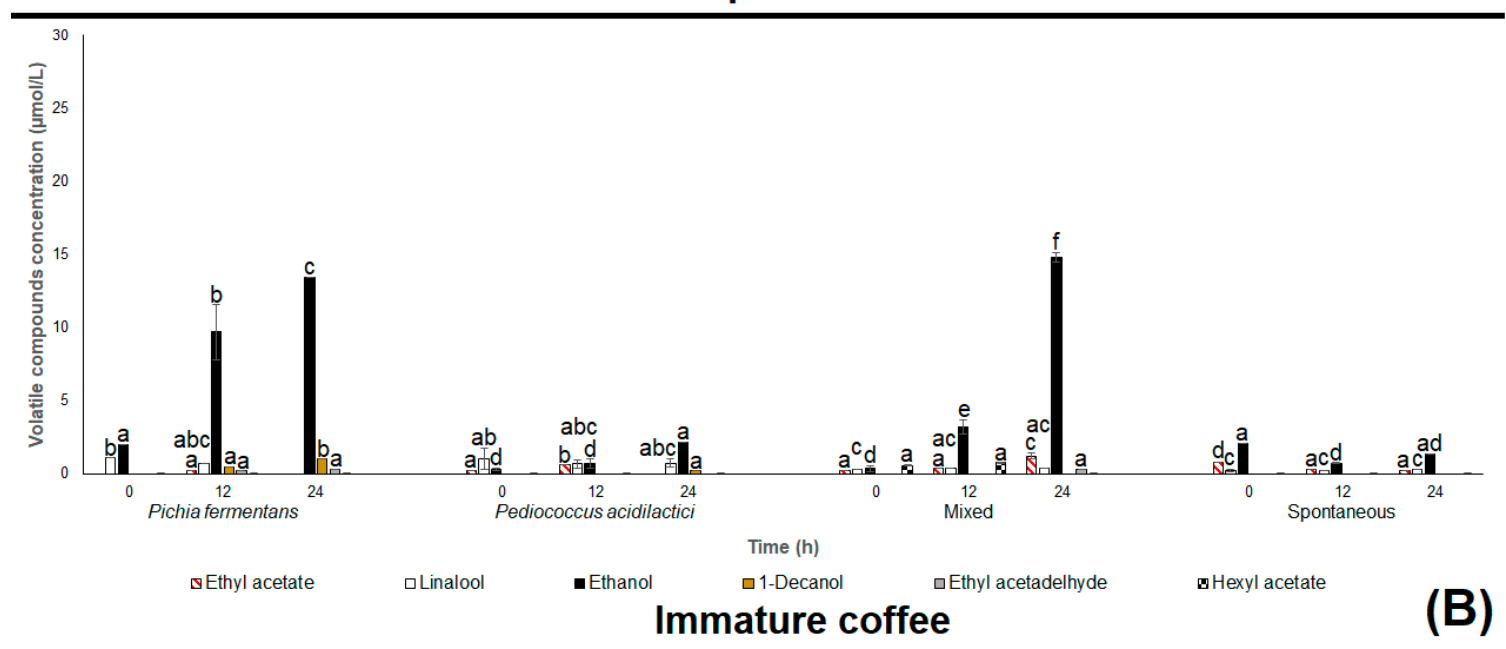

Figure 2. Concentration of volatile compounds produced in the course inoculated (pure culture with $P$. fermentans, pure culture with $P$. acidilactici, and combined fermentation with $P$. fermentans and $P$. acidilactici) and spontaneous fermentation of ripe (A) and immature (B) coffee fruits. The significance of the results was assessed using an ANOVA with Duncan's post-hoc test at $p<0.05$. Different lowercase letters $(a, b, c, d, e, f)$ indicate significant differences within the same process (ripe and immature coffee beans) over fermentation time.

Other minor volatile compounds that increased during the fermentation processes were 1-decanol, ethyl-acetaldehyde, and hexyl acetate (Figure 2). Yeast and lactic acid bacteria generate ethyl-acetaldehyde by a condensation reaction between fatty acids and an alcohol molecule [41], while 1-decanol can be derived from amino acid catabolism via the Ehrlich pathway $[16,42]$. The presence of higher concentrations of linalool using immature fruits can be associated with the inferior maturation stage of the coffee beans, since this compound has been considered a volatile marker of coffee beverages produced from immature fruits [43]. 


\subsection{Coffee Beans Chemical Composition}

Over 900 volatile compounds have already been identified in green and roasted coffee beans $[27,44]$. Among the major volatiles found, pyrazines, furans, ketones, aldehydes, higher alcohols, esters, and sulphur compounds can be highlighted [45-47]. Although some of these flavor-active compounds originate from the beans itself, recent studies have revealed that microbial-derived metabolites can also diffuse into the beans $[11,14,27,33,48-50]$. Upon characterization of the volatile composition of fermented coffee beans, it was observed that inoculation of P. fermentans and P. acidilactici, both in pure and combined treatments, resulted in the modulation of the volatile constitution of coffee beans. A total of 30 compounds were identified in fermented ripe coffee beans, including higher alcohols (seven compounds), aldehydes (six compounds), and terpenes (three compounds; Table 1). Among these, 1-hexanol, 2-heptanol, phenylethyl alcohol, and benzeneacetaldehyde were the major volatiles found. Single inoculation of P. fermentans and P. acidilactici resulted in the formation and diffusion of some volatile compounds, such as 3-octanol, 2-heptenal, benzaldehyde, dodecanal, and D-limonene, that were not detected in a spontaneous process. These compounds are strictly related to both yeast and LAB metabolism, such as aldehydes and higher alcohols formed from the catabolism of coffee pulp amino acids, and terpenes through mevalonic acid pathway or released from glycoside precursors during fermentation $[10,51,52]$. 
Table 1. Concentration of volatile compounds (Area*10 $0^{5}$ in ripe coffee beans after single cultures, a combined treatment, and a spontaneous assay. Means of triplicate in each row bearing the same lowercase letters $(a, b)$ are not significantly different $(p>0.05)$ from one another using Duncan's Test $(m e a n \pm$ standard variation).

\begin{tabular}{|c|c|c|c|c|c|}
\hline \multirow{2}{*}{ Compounds } & \multirow{2}{*}{ Aroma Perception } & \multicolumn{4}{|c|}{ Fermented Ripe Coffee Beans } \\
\hline & & Spontaneous & P. fermentans & P. acidilactici & P. fermentans $+P$. acidilactici \\
\hline \multicolumn{6}{|l|}{ Organic acids (3) } \\
\hline Butanoic acid, 3-methyl & - & $7.02 \pm 1.00^{\mathrm{a}}$ & $6.88 \pm 1.48^{\mathrm{a}}$ & $6.10 \pm 1.74^{\mathrm{a}}$ & $6.91 \pm 0.18^{a}$ \\
\hline Butanoic acid, 2-methyl & Fruity, dirty, acidic with a dairy buttery & $1.77 \pm 0.35^{\mathrm{a}}$ & $1.98 \pm 0.28^{\mathrm{a}}$ & $\mathrm{ND}$ & $1.79 \pm 0.28^{a}$ \\
\hline Hexanoic acid & Sour, fatty, sweat, cheesy & ND & $1.34 \pm 0.61^{\mathrm{a}}$ & $0.99 \pm 0.23^{a}$ & $1.67 \pm 0.88^{\mathrm{a}}$ \\
\hline \multicolumn{6}{|l|}{ Higher alcohols (7) } \\
\hline 2-Heptanol & Fresh, lemon grass, herbal & $10.21 \pm 0.00^{\mathrm{a}}$ & ND & ND & $12.12 \pm 0.10^{\mathrm{b}}$ \\
\hline 5-Methyl-2-Hexanol & - & $6.09 \pm 2.66$ & $\mathrm{ND}$ & ND & $\mathrm{ND}$ \\
\hline 1-Hexanol & Green, fruity, apple-skin and oily & $15.90 \pm 2.36^{\mathrm{a}}$ & $16.95 \pm 2.23^{\mathrm{a}}$ & $17.10 \pm 2.36^{\mathrm{a}}$ & $18.24 \pm 0.17^{\mathrm{a}}$ \\
\hline 1-Octen-3-ol & Earthy, green, oily, umami sensation & $0.82 \pm 0.00^{\mathrm{a}}$ & $0.80 \pm 0.17^{\mathrm{a}}$ & ND & $0.86 \pm 0.03^{\mathrm{a}}$ \\
\hline 3-Octanol & Musty, mushroom, earthy, creamy dairy & ND & $0.50 \pm 0.14^{\mathrm{a}}$ & $0.58 \pm 0.00^{\mathrm{a}}$ & $0.67 \pm 0.00^{\mathrm{a}}$ \\
\hline Benzylalcohol & Sweet, fruity with balsamic nuances & $2.58 \pm 0.05^{\mathrm{a}}$ & $3.26 \pm 0.36^{\mathrm{a}}$ & $3.20 \pm 0.68^{a}$ & $4.31 \pm 0.17^{b}$ \\
\hline Phenylethyl alcohol & Floral, sweet and bready & $9.52 \pm 0.73^{a}$ & $10.34 \pm 0.41^{\mathrm{a}}$ & $12.17 \pm 0.25^{\mathrm{b}}$ & $12.60 \pm 1.31^{\mathrm{b}}$ \\
\hline \multicolumn{6}{|l|}{ Esters (3) } \\
\hline Butanoic acid, 2-methyl, ethyl ester & - & $0.58 \pm 0.26^{\mathrm{a}}$ & $0.34 \pm 0.00^{\mathrm{a}}$ & ND & $0.54 \pm 0.20^{\mathrm{a}}$ \\
\hline Butanoic acid, 3-methyl- ethyl ester & - & $4.62 \pm 0.59^{\mathrm{a}}$ & $3.66 \pm 1.71^{\mathrm{a}}$ & ND & $4.70 \pm 0.57^{\mathrm{a}}$ \\
\hline Methyl salicylate & Wintergreen, mint-like & ND & $0.28 \pm 0.01$ & ND & ND \\
\hline \multicolumn{6}{|l|}{ Aldehydes (6) } \\
\hline 2-Heptenal & Sweet, fresh fruity apple skin nuances & ND & $0.80 \pm 0.00^{\mathrm{a}}$ & ND & $0.80 \pm 0.00^{\mathrm{a}}$ \\
\hline Benzaldehyde & Fruity, cherry & ND & $0.32 \pm 0.00^{\mathrm{a}}$ & $2.15 \pm 0.84^{\mathrm{a}}$ & $2.56 \pm 0.69^{a}$ \\
\hline Dodecanal & Soapy, waxy, citrus, orange mandarin & ND & ND & $0.23 \pm 0.14$ & ND \\
\hline Nonanal & $\begin{array}{l}\text { With a fresh green lemon peel-like } \\
\text { nuance }\end{array}$ & $0.95 \pm 0.05^{\mathrm{a}}$ & $0.93 \pm 0.35^{\mathrm{a}}$ & $0.81 \pm 0.06^{\mathrm{a}}$ & $0.84 \pm 0.27^{a}$ \\
\hline Benzeneacetaldehyde & Almond, fruity, powdery, nutty & $1.83 \pm 0.29^{\mathrm{a}}$ & $2.80 \pm 0.73^{\mathrm{a}}$ & $2.28 \pm 0.04^{\mathrm{a}}$ & $6.94 \pm 0.00^{b}$ \\
\hline Decanal & $\begin{array}{l}\text { Sweet, aldehydic, orange, waxy and } \\
\text { citrus rind }\end{array}$ & ND & $0.37 \pm 0.11^{\mathrm{a}}$ & $0.37 \pm 0.09^{\mathrm{a}}$ & $0.34 \pm 0.07^{\mathrm{a}}$ \\
\hline \multicolumn{6}{|l|}{ Ketone (1) } \\
\hline 2-Heptanone & Fruity, spice, herbal & $3.49 \pm 0.69^{a}$ & $2.92 \pm 0.28^{a}$ & $2.29 \pm 0.90^{a}$ & $4.38 \pm 1.75^{\mathrm{a}}$ \\
\hline
\end{tabular}


Table 1. Cont.

\begin{tabular}{|c|c|c|c|c|c|}
\hline \multirow{2}{*}{ Compounds } & \multirow{2}{*}{ Aroma Perception } & \multicolumn{4}{|c|}{ Fermented Ripe Coffee Beans } \\
\hline & & Spontaneous & P. fermentans & P. acidilactici & P. fermentans + P. acidilactici \\
\hline \multicolumn{6}{|l|}{ Pyridine (2) } \\
\hline Pyridine, 2,3-dimethyl & - & ND & $1.55 \pm 0.94^{\mathrm{a}}$ & $1.44 \pm 0.26^{\mathrm{a}}$ & $1.25 \pm 0.63^{\mathrm{a}}$ \\
\hline Pyridine, 2,6-Lutidine & $\begin{array}{l}\text { Nutty, amine, woody, bready and } \\
\text { vegetable-like }\end{array}$ & $1.85 \pm 0.19$ & ND & ND & ND \\
\hline \multicolumn{6}{|l|}{ Lactone (1) } \\
\hline Butyrolactone & Creamy, oily, fatty, caramellic & $5.28 \pm 0.10^{\mathrm{a}}$ & $6.17 \pm 1.04^{\mathrm{a}}$ & $4.86 \pm 1.13^{\mathrm{a}}$ & $6.09 \pm 0.13^{\mathrm{a}}$ \\
\hline \multicolumn{6}{|l|}{ Terpenes (3) } \\
\hline Linalool & Citrus, orange, lemon & $2.36 \pm 0.29^{a}$ & $2.27 \pm 0.21^{\mathrm{a}}$ & $2.22 \pm 0.82^{\mathrm{a}}$ & $2.92 \pm 0.17^{b}$ \\
\hline D-Limonene & Sweet, orange, citrus & ND & $1.29 \pm 0.60^{\mathrm{a}}$ & $1.37 \pm 0.49^{\mathrm{a}}$ & $1.42 \pm 0.35^{\mathrm{a}}$ \\
\hline Anethole & - & $4.10 \pm 1.00^{b}$ & $1.87 \pm 0.26^{\mathrm{a}}$ & $1.96 \pm 0.66^{\mathrm{a}}$ & $3.13 \pm 0.20 \mathrm{a}, \mathrm{b}$ \\
\hline \multicolumn{6}{|l|}{ Hydrocarbons (2) } \\
\hline Styrene & Sweet, balsamic, floral & ND & $2.89 \pm 0.00^{\mathrm{a}}$ & ND & $3.15 \pm 0.00^{\mathrm{a}}$ \\
\hline Tetradecane & Waxy & $0.91 \pm 0.07^{\mathrm{a}}$ & $0.82 \pm 0.06^{\mathrm{a}}$ & $0.88 \pm 0.16^{\mathrm{a}}$ & $0.80 \pm 0.06^{\mathrm{a}}$ \\
\hline \multicolumn{6}{|l|}{ Pyrzine (1) } \\
\hline Pyrazine, 2-methoxy-3-(2-methylpropyl) & Roasted almond hazelnut peanut & $0.92 \pm 0.04^{\mathrm{a}}$ & ND & $0.93 \pm 0.08^{\mathrm{a}}$ & ND \\
\hline \multicolumn{6}{|l|}{ Furan $(1)$} \\
\hline Furan, 2-pentyl & $\begin{array}{c}\text { Waxy, with musty, cooked caramellic } \\
\text { nuances }\end{array}$ & $1.16 \pm 0.04$ & ND & ND & ND \\
\hline
\end{tabular}


Interestingly, coffee beans generated from combined treatments showed significantly increased $(p<0.05)$ of specific volatile compounds, such as benzeneacetaldehyde, 2-heptanol, and benzylalcohol. These findings are in accordance with Englezos et al. [18] and Plessas et al. [53], which evidences that mixed treatments of yeast and LAB starter cultures enable higher production of esters, aldehydes, and higher alcohols in sourdough and wine fermentations when compared to single inoculations. However, further studies are required to evidence the metabolic pathways associated with the positive interaction between these microorganisms in coffee products.

Chemical analysis of immature coffee beans revealed a composition with lower diversity and concentration of volatile compounds (Table 2). A total of 19 compounds were detected, including higher alcohols (four compounds), organic acids (three compounds), and aldehydes (three compounds). $P$. fermentans-single inoculation resulted in coffee beans with significantly higher concentrations $(p<0.05)$ of 2-hexanol, nonanal, and D-limonene when compared to the spontaneous process. These compounds are commonly attributed to Pichia metabolism $[10,54,55]$. This corroborates with results from fermentation process monitoring, which demonstrated intense microbial activity of P. fermentans in immature coffee pulp. On the other hand, coffee beans derived from P. acidilactici-pure culture and combined treatment showed no significant increase $(p>0.05)$ in the volatile constituents when compared to the control (spontaneous process). This fact can be correlated to the insufficient growth of the LAB starter culture in the nutrient-scarce environment from the pulp of immature coffee beans. The auxotrophism of several amino acids turns LAB directly dependent on a rich growth medium for its full development [31]. 
Table 2. Concentration of volatile compounds (Area*10 ${ }^{5}$ ) in immature coffee beans after single cultures, a combined treatment, and a spontaneous assay. Means of triplicate in each row bearing the same lowercase letters $(a, b, c)$ are not significantly different $(p>0.05)$ from one another using Duncan's Test (mean \pm standard variation).

\begin{tabular}{|c|c|c|c|c|c|}
\hline \multirow{2}{*}{ Compounds } & \multirow{2}{*}{ Aroma Perception } & \multicolumn{4}{|c|}{ Fermented Immature Coffee Beans } \\
\hline & & Spontaneous & P. fermentans & P. acidilactici & P. fermentans $+P$. acidilactici \\
\hline \multicolumn{6}{|l|}{ Organic acids (3) } \\
\hline Butanoic acid, 3-methyl & - & $7.77 \pm 1.05^{\mathrm{a}}$ & $5.99 \pm 2.31^{\mathrm{a}}$ & $8.56 \pm 1.57^{a, b}$ & $5.15 \pm 0.98^{\mathrm{a}, \mathrm{c}}$ \\
\hline Butanoic acid, 2-methyl & Fruity, acidic with a dairy buttery & $1.32 \pm 0.36^{\mathrm{a}}$ & $1.24 \pm 0.86^{\mathrm{a}}$ & $1.65 \pm 0.13^{a, b}$ & $0.69 \pm 0.15^{\mathrm{a}, \mathrm{c}}$ \\
\hline Hexanoic acid & Sour, fatty, sweat, cheesy & ND & $0.63 \pm 0.15^{\mathrm{a}}$ & $0.50 \pm 0.11^{\mathrm{a}}$ & ND \\
\hline \multicolumn{6}{|l|}{ Higher alcohols (4) } \\
\hline 1-Hexanol & Green, fruity, apple-skin and oily & $10.02 \pm 0.26^{\mathrm{a}}$ & $10.57 \pm 1.33^{\text {a }}$ & $9.14 \pm 1.51^{\mathrm{a}}$ & $9.85 \pm 1.17^{\mathrm{a}}$ \\
\hline 2-Hexanol & - & $0.36 \pm 0.05^{\mathrm{a}}$ & $0.75 \pm 0.01 \mathrm{~b}$ & ND & $0.45 \pm 0.10^{\mathrm{a}}$ \\
\hline Benzylalcohol & Sweet, fruity with balsamic nuances & $0.54 \pm 0.15^{\mathrm{a}}$ & $0.62 \pm 0.08^{a}$ & $0.51 \pm 0.20^{\mathrm{a}}$ & $0.61 \pm 0.04^{\mathrm{a}}$ \\
\hline Phenylethyl alcohol & Floral, sweet and bready & $2.54 \pm 0.38^{a}$ & $2.78 \pm 0.17^{b}$ & $2.24 \pm 0.12^{\mathrm{a}}$ & $2.20 \pm 0.18^{a}$ \\
\hline \multicolumn{6}{|l|}{ Aldehydes (3) } \\
\hline Nonanal & $\begin{array}{l}\text { Citrus, with a fresh green lemon peel-like } \\
\text { nuance }\end{array}$ & $0.30 \pm 0.08^{a}$ & $0.74 \pm 0.04^{b}$ & $0.46 \pm 0.07^{c, d}$ & $0.48 \pm 0.05^{\mathrm{d}}$ \\
\hline Benzeneacetaldehyde & Almond, fruity, powdery, nutty & $0.21 \pm 0.00^{\mathrm{a}}$ & $0.28 \pm 0.01^{\mathrm{a}}$ & $0.27 \pm 0.13^{\mathrm{a}}$ & $0.38 \pm 0.00^{a}$ \\
\hline Decanal & Sweet, orange, waxy and citrus rind & $0.24 \pm 0.09^{a}$ & $0.43 \pm 0.06^{\mathrm{a}}$ & $0.30 \pm 0.10^{\mathrm{a}}$ & $0.42 \pm 0.08^{\mathrm{a}}$ \\
\hline \multicolumn{6}{|l|}{ Pyridines (2) } \\
\hline Pyridine, 2,3-dimethyl & - & ND & $1.45 \pm 0.34^{\mathrm{a}}$ & $0.62 \pm 0.14^{\mathrm{a}}$ & $1.10 \pm 0.36^{\mathrm{a}}$ \\
\hline Pyridine, 2,6-Lutidine & Nutty, woody, bready and vegetable-like & $0.95 \pm 0.35$ & ND & ND & ND \\
\hline \multicolumn{6}{|l|}{ Lactone (1) } \\
\hline Butyrolactone & Creamy, oily, fatty, caramellic & $0.92 \pm 0.07^{\mathrm{a}}$ & $0.46 \pm 0.20^{a}$ & $0.66 \pm 0.26^{\mathrm{a}}$ & $0.49 \pm 0.17^{\mathrm{a}}$ \\
\hline \multicolumn{6}{|l|}{ Terpenes (1) } \\
\hline D-Limonene & Sweet, orange, citrus & $0.36 \pm 0.06^{\mathrm{a}}$ & $0.72 \pm 0.16^{b}$ & $0.16 \pm 0.09^{c}$ & $0.41 \pm 0.19^{\mathrm{a}}$ \\
\hline
\end{tabular}


Table 2. Cont

\begin{tabular}{|c|c|c|c|c|c|}
\hline \multirow{2}{*}{ Compounds } & \multirow{2}{*}{ Aroma Perception } & \multicolumn{4}{|c|}{ Fermented Immature Coffee Beans } \\
\hline & & Spontaneous & P. fermentans & P. acidilactici & P. fermentans $+P$. acidilactici \\
\hline \multicolumn{6}{|l|}{ Furans (2) } \\
\hline Furan-2-pentyl & Waxy, cooked caramellic nuances & $0.57 \pm 0.17^{\mathrm{a}}$ & $0.74 \pm 0.12^{\mathrm{a}}$ & $0.58 \pm 0.15^{\mathrm{a}}$ & $0.69 \pm 0.13^{\mathrm{a}}$ \\
\hline 2(3)-Furanone, dihydro-5-methyl & Creamy, waxy with a citrus fruity nuance & $0.55 \pm 0.14^{\mathrm{a}}$ & $0.38 \pm 0.16^{\mathrm{a}}$ & ND & $0.45 \pm 0.15^{\mathrm{a}}$ \\
\hline \multicolumn{6}{|l|}{ Hydrocarbons (2) } \\
\hline Hexadecane & - & ND & $0.55 \pm 0.01$ & ND & ND \\
\hline Tetradecane & Waxy & $0.62 \pm 0.02^{a}$ & $0.24 \pm 0.07^{b}$ & $0.30 \pm 0.06^{c}$ & $0.76 \pm 0.10^{a, c}$ \\
\hline \multicolumn{6}{|l|}{ Pyrzine (1) } \\
\hline Pyrazine, 2-methoxy-3-(2-methylpropyl) & Roasted almond hazelnut peanut & $0.78 \pm 0.07^{\mathrm{a}}$ & $0.80 \pm 0.01^{\mathrm{a}}$ & $0.85 \pm 0.12^{\mathrm{a}}$ & $0.92 \pm 0.08^{\mathrm{a}}$ \\
\hline
\end{tabular}


In order to explain the chemical characteristics and grouping of the samples, the parameters in Tables 1 and 2 were analyzed by a PCA (Figure 3). The first and second principal components explained, together, $73.66 \%$ of the total variability within the data. The samples were categorized into two clusters, viz., ripe and immature coffee beans. This distinction was mainly related to the richer constitution of volatiles of ripe coffee beans relative to immature treatments. In addition, the presence of specific compounds (benzyl alcohol, phenylethyl alcohol, benzeneacetaldehyde, decanal, and D-limonene in ripe coffee beans, and furan-2-pentyl, 2-methyl-butanoic acid, and pyrazine, 2-methoxy-3-(2-methylpropyl) in immature coffee beans) also contributed to the separation of ripe and immature coffee beans in the PCA analysis. Interestingly, only the treatment with P. fermentans grouped immature coffee beans in the positive axis, which corroborates with the better yeast' adaptation and generation of volatiles in immature coffee pulp.

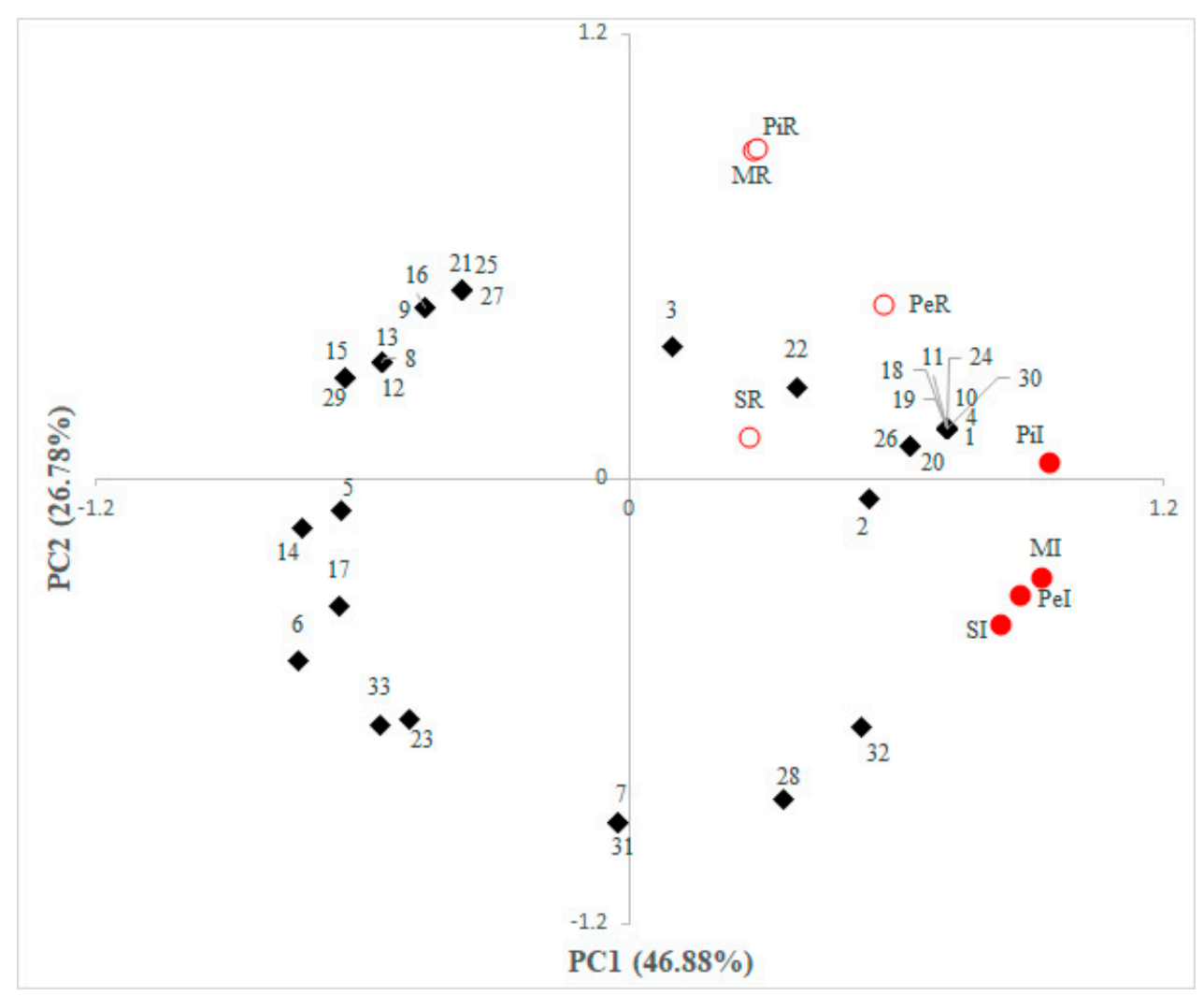

Figure 3. Principal component analysis (PCA) of volatile compounds (lozenges) identified in the different treatments of ripe (open circles) and immature (closed circles) coffee beans. Abbreviations: $S R$-spontaneous, ripe control; PiR-Pichia inoculation in ripe coffee beans; PeR-Pediococcus inoculation in ripe coffee beans; $M R$-mixed (Pichia plus Pediococcus) inoculation in ripe coffee beans; SI-spontaneous, immature control; PiI-Pichia inoculation in immature coffee beans; PeI-Pediococcus inoculation in immature coffee beans; MI-mixed (Pichia plus Pediococcus) inoculation in immature coffee beans. 1-butanoic acid, 3-methyl; 2-butanoic acid, 2-methyl; 3-hexanoic acid; 4-1-hexanol; 5-2-heptanol; 6-5-methyl-2-hexanol; 7-2-hexanol; 8-1-octen-3-ol; 9-3-octanol; 10-benzylalcohol; 11-phenylethyl alcohol; 12-butanoic acid, 2-methyl, ethyl ester; 13 - butanoic acid, 2-methyl, ethyl ester; 14-methyl salicylate; 15-2-heptenal; 16-benzaldehyde; 17-dodecanal; 18-nonanal; 19-benzeneacetaldehyde; 20-decanal; 21-2-heptanone; 22-pyridine, 2,3-dimethyl; 23-pyridine, 2,6-lutidine; 24-butyrolactone; 25-linalool; 26-D-limonene; 27-anethole; 28-furan-2-pentyl; 29-styrene; 30-tetradecane; 31-2(3)-furanone, dihydro-5-methyl; 32-pyrazine, 2-methoxy-3-(2-methylpropyl); 33-hexadecane. 


\section{Conclusions}

This is the first study investigating the impact of co-inoculation with yeast and LAB on the fermentation of ripe and immature coffee fruits. Among the different treatments, combined inoculations with Pichia fermentans YC5.2 and Pediococcus acidilactici LPBC161 in ripe coffee fruits showed interesting features. It was possible to reach increased coffee pulp-sugar consumption and production of metabolites (lactic acid, ethanol, and ethyl acetate), evidencing a positive synergic interaction between these two microbial groups. On the other hand, when using immature coffee fruits, only Pichia fermentans was able to improve metabolite formation during fermentation and impact volatile composition of resulting coffee beans. This may be due to the high nutritional requirement of LAB species and poor adaptability in immature coffee pulp. Howsoever, since immature coffee beans usually have a low quality because the formation of flavored precursors is incomplete, yeast metabolism has great potential to add flavor quality to these beans.

Chemical analysis revealed a more complex volatile composition of fermented coffee beans from combined treatment in relation to pure inoculations and spontaneous process. The major compounds impacted were benzeneacetaldehyde, 1-hexanol, benzylalcohol, 2-heptanol, and phenylethyl alcohol, which are reported as important aroma-impacting compounds. Thus, this study shows the great potential of combined inoculation for the formation of desirable aroma compounds and production of specialty coffees. Further studies are still required to investigate the mechanisms of synergism between yeast and LAB and influence on sensory properties of coffee products.

Author Contributions: C.R.S. and G.V.d.M.P. designed the experiments. C.R. conducted the physicochemical characterization of fermenting coffee pulp. A.d.S.V. and D.P.d.C.N. performed the experiments and wrote the manuscript. C.R.S., G.V.d.M.P., and M.G.B.P., reviewed and edited the manuscript. All authors read and approved the final manuscript.

Funding: This work was supported by the Brazilian National Council for Scientific and Technological Development (CNPq) (project number 429560/2018-4).

Conflicts of Interest: The authors declare no conflict of interest.

\section{References}

1. Huch, M.; Franz, C.M.A.P. Coffee: Fermentation and microbiota. In Advances in Fermented Foods and Beverages: Improving Quality, Technologies and Health Benefits, 1st ed.; Holzapfel, W., Ed.; Woodhead Publishing: Sawston, UK, 2015; Volume 4, pp. 501-513.

2. DaMatta, F.M.; Ronchi, C.P.; Maestri, M.; Barros, R.S. Ecophysiology of coffee growth and production. Braz. J. Plant Physiol. 2007, 19, 485-510. [CrossRef]

3. Mesquita, C.M.; Rezende, J.E.; De Carvalho, J.S.; Junior, M.A.F.; Moraes, N.C.; Dias, P.T.; Carvalho, R.M.; de Araújo, W.G. Manual do café: Colheita e preparo; Emater: Belo Horizonte, Brazil, 2016; pp. 6-21.

4. Franca, A.S.; Oliveira, L.S.; Mendonça, J.C.F.; Silva, X.A. Physical and chemical attributes of defective crude and roasted coffee beans. Food Chem. 2005, 90, 89-94. [CrossRef]

5. Oliveira, L.S.; Franca, A.S.; Mendonça, J.C.F.; Barros-Júnior, M.C. Proximate composition and fatty acids profile of green and roasted defective coffee beans. LWT Food Sci. Technol. 2006, 39, 235-239. [CrossRef]

6. Bee, S.; Brando, C.H.J.; Brumen, G.; Carvalhaes, N.; Kölling-Speer, I.; Speer, K.; Liverani, F.S.; Teixeira, A.A.; Thomaziello, R.A.; Viani, R.; et al. The raw coffee. In Expresso Coffee: The Science of Quality; Illy, A., Vinai, R., Eds.; Elsevier Academic Press: London, UK, 2005; pp. 87-178.

7. Illy, E. The complexity of coffee. Sci. Am. 2002, 286, 86-91. [CrossRef] [PubMed]

8. De Bruyn, F.; Zhang, S.J.; Pothakos, V.; Torres, J.; Lambot, C.; Moroni, A.V.; Callanan, M.; Sybesma, W.; Weckx, S.; De Vuyst, L. Exploring the impacts of postharvest processing on the microbiota and metabolite profiles during green coffee bean production. Appl. Environ. Microbiol. 2017, 83, e02398-16. [CrossRef] [PubMed]

9. Pereira, G.V.M.; Soccol, V.T.; Brar, S.K.; Neto, E.; Soccol, C.R. Microbial ecology and starter culture technology in coffee processing. Crit. Rev. Food Sci. Nutr. 2017, 57, 2775-2788. [CrossRef] [PubMed] 
10. Pereira, G.V.M.; Carvalho Neto, D.P.; Júnior, A.I.M.; Vásquez, Z.S.; Medeiros, A.B.P.; Vandenberghe, L.P.S.; Soccol, C.R. Exploring the impacts of postharvest processing on the aroma formation of coffee beans-A review. Food Chem. 2019, 272, 441-452. [CrossRef] [PubMed]

11. Wang, C.; Sun, J.; Lassabliere, B.; Yu, B.; Zhao, F.; Zhao, F.; Chen, Y.; Liu, S.Q. Potential of lactic acid bacteria to modulate coffee volatiles and effect of glucose supplementation: Fermentation of green coffee beans and impact of coffee roasting. J. Sci. Food Agric. 2019, 99, 409-420. [CrossRef]

12. Lee, L.W.; Cheong, M.W.; Curran, P.; Yu, B.; Liu, S.Q. Modulation of coffee aroma via the fermentation of green coffee beans with Rhizopus oligosporus: I. Green coffee. Food Chem. 2016, 211, 916-924. [CrossRef]

13. Pereira, G.V.M.; Carvalho Neto, D.P.; Medeiros, A.B.P.; Soccol, V.T.; Neto, E.; Woiciechowski, A.L.; Soccol, C.R. Potential of lactic acid bacteria to improve the fermentation and quality of coffee during on-farm processing. Int. J. Food Sci. Technol. 2016, 51, 1689-1695. [CrossRef]

14. Pereira, G.V.M.; Neto, E.; Soccol, V.T.; Medeiros, A.B.P.; Woiciechowski, A.L.; Soccol, C.R. Conducting starter culture-controlled fermentations of coffee beans during on-farm wet processing: Growth, metabolic analyses and sensorial effects. Food Res. Int. 2015, 75, 348-356. [CrossRef] [PubMed]

15. Muynarsk, E.S.M.; Pereira, G.V.M.; Mesa, D.; Thomaz-Soccol, V.; Carvalho, J.C.; Pagnoncelli, M.G.B.; Soccol, C.R. Draft genome sequence of Pediococcus acidilactici strain LPBC161, isolated from mature coffee cherries during natural fermentation. Microbiol. Resour. Announc. 2019, 8, e00332-19. [CrossRef] [PubMed]

16. Pereira, G.V.M.; Soccol, V.T.; Pandey, A.; Medeiros, A.B.P.; Lara, J.M.R.A.; Gollo, A.L.; Soccol, C.R. Isolation, selection and evaluation of yeasts for use in fermentation of coffee beans by the wet process. Int. J. Food Microbiol. 2014, 188, 60-66. [CrossRef] [PubMed]

17. Xia, X.; Luo, Y.; Zhang, Q.; Huang, Y.; Zhang, B. Mixed starter culture regulates biogenic amines formation via decarboxylation and transamination during Chinese rice wine fermentation. J. Agric. Food Chem. 2018, 66, 6348-6356. [CrossRef] [PubMed]

18. Englezos, V.; Torchio, F.; Cravero, F.; Marengo, F.; Giacosa, S.; Gerbi, V.; Rantsiou, K.; Rolle, L.; Cocolin, L. Aroma profile and composition of Barbera wines obtained by mixed fermentations of Starmerella bacillaris (synonym Candida zemplinina) and Saccharomyces cerevisiae. LWT Food Sci. Technol. 2016, 73, 567-575. [CrossRef]

19. Feltrin, V.P.; Sant'Anna, E.S.; Porto, A.C.S.; Torres, R.C.O. Produção de Lactobacillus plantarum em melaço de cana-de-açûcar. Braz. Arch. Biol. Technol. 2000, 43, 119-124. [CrossRef]

20. Carvalho Neto, D.P.; Pereira, G.V.M.; Tanobe, V.O.A.; Thomaz-Soccol, V.; da Silva, B.G.J.; Rodrigues, C.; Soccol, C.R. Yeast diversity and physicochemical characteristics associated with coffee bean fermentation from the Brazilian cerrado mineiro region. Fermentation 2017, 3, 11. [CrossRef]

21. Gobbi, M.; Comitini, F.; Domizio, P.; Romani, C.; Lencioni, L.; Mannazzu, I.; Ciani, M. Lachancea thermotolerans and Saccharomyces cerevisiae in simultaneous and sequential co-fermentation: A strategy to enhance acidity and improve the overall quality of wine. Food Microbiol. 2013, 33, 271-281. [CrossRef]

22. Cinai, M.; Comitini, F.; Mannazzu, I.; Domizio, P. Controlled mixed culture fermentation: A new perspective on the use of non-Saccharomyces yeasts in winemaking. FEMS Yeast Res. 2010, 10, 123-133. [CrossRef]

23. Gaden, E.L., Jr.; Bokanga, M.; Harlander, S.; Hesseltine, C.W.; Steinkraus, K.H. Applications of Biotechnology to Traditional Fermented Foods; National Academy Press: Washington, DC, USA, 1992.

24. Eira, M.T.S.; da Silva, E.A.A.; de Castro, R.D.; Dussert, S.; Walters, C.; Bewley, J.D.; Hilhorst, W.M. Coffee seed physiology. Braz. J. Plant Physiol. 2006, 18, 149-163. [CrossRef]

25. Marques, W.L.; Raghavendran, V.; Stambuk, B.U.; Gombert, A.K. Sucrose and Saccharomyces cerevisiae: A relationship most sweet. FEMS Yeast Res. 2016, 16, fov107. [CrossRef] [PubMed]

26. Murthy, P.S.; Naidu, M. Improvement of Robusta coffee fermentation with microbial enzymes. Eur. J. Appl. Sci. 2011, 3, 130-139.

27. Evangelista, S.R.; Miguel, M.G.C.P.; Cordeiro, C.S.; Silva, C.F.; Pinheiro, A.C.M.; Schwan, R.F. Inoculation of starter cultures in a semi-dry coffee (Coffea arabica) fermentation process. Food Microbiol. 2014, 44, 87-95. [CrossRef] [PubMed]

28. Evangelista, S.R.; Silva, C.F.; Miguel, M.G.P.C.; Cordeiro, C.S.; Pinheiro, A.C.M.; Duarte, W.F.; Schwan, R.F. Improvement of coffee beverage quality by using selected yeasts strains during the fermentation in dry process. Food Res. Int. 2014, 61, 183-195. [CrossRef]

29. Avallone, S.; Brillouet, J.M.; Guyot, B.; Olguin, E.; Guiraud, J.P. Involvement of pectolytic micro-organisms in coffee fermentation. Int. J. Food Sci. Technol. 2002, 37, 191-198. [CrossRef] 
30. Muñoz, R.; Moreno-Arribas, M.V.; de las Rivas, B. Lactic acid bacteria. In Molecular Wine Microbiology, 1st ed.; Carrascosa, A.V., Muñoz, R., González, R., Eds.; Academic Press: Burlington, VT, USA, 2011; pp. 191-226.

31. Endo, A.; Dicks, L.M.T. Physiology of the LAB. In Lactic Acid Bacteria: Biodiversity and Taxonomy; Holzapfel, W.H., Wood, B.J.B., Eds.; Wiley Blackwell: Chichester, UK, 2014; pp. 13-30.

32. Rantsiou, K.; Dolci, P.; Giacosa, S.; Torchio, F.; Tofalo, R.; Torriani, S.; Suzzi, G.; Rolle, L.; Cocolin, L. Candida zemplinina can reduce acetic acid produced by Saccharomyces cerevisiae in sweet wine fermentations. Appl. Environ. Microbiol. 2012, 78, 1987-1994. [CrossRef] [PubMed]

33. Carvalho Neto, D.P.; Pereira, G.V.M.; Finco, A.M.O.; Letti, L.A.J.; Silva, B.J.G.; Vandenberghe, L.P.S.; Soccol, C.R. Efficient coffee beans mucilage layer removal using lactic acid fermentation in a stirred-tank bioreactor: Kinetic, metabolic and sensorial studies. Food Biosci. 2018, 26, 80-87. [CrossRef]

34. Velmourougane, K. Impact of natural fermentation on physicochemical, microbiological and cup quality characteristics of Arabica and Robusta coffee. Proc. Natl. Acad. Sci. USA India Sect. B Biol. Sci. 2013, 83, 233-239. [CrossRef]

35. Jackels, S.C.; Jackels, C.F. Characterization of the coffee mucilage fermentation process using chemical indicators: A field study in Nicaragua. Food Chem. Toxicol. 2005, 70, 321-325. [CrossRef]

36. Sun, S.Y.; Gong, H.S.; Zhao, K.; Wang, X.L.; Wang, X.; Zhao, X.H.; Yu, B.; Wang, H.X. Co-inoculation of yeast and lactic acid bacteria to improve cherry wines sensory quality. Int. J. Food Sci. Technol. 2013, 48, 1783-1790. [CrossRef]

37. Cañas, P.M.I.; Romero, E.G.; Pérez-Martín, F.; Seseña, S.; Palop, M.L. Sequential inoculation versus co-inoculation in Cabernet Franc wine fermentation. Food Sci. Technol. Int. 2015, 21, 203-212. [CrossRef] [PubMed]

38. Alexandre, H.; Guilloux-Benatier, M. Yeast autolysis in sparkling wine-A review. Aust. J. Grape Wine Res. 2006, 12, 119-127. [CrossRef]

39. Fleet, G.H. Yeast interactions and wine flavour. Int. J. Food Microbiol. 2003, 86, 11-22. [CrossRef]

40. Junqueira, A.C.O.; Pereira, G.V.M.; Medina, J.D.C.; Alvear, M.C.R.; Rosero, R.; Carvalho Neto, D.P.; Enríquez, H.G.; Soccol, C.R. First description of bacterial and fungal communities in Colombian coffee beans fermentation analysed using Illumina-based amplicon sequencing. Sci. Rep. 2019, 9, 8794. [CrossRef] [PubMed]

41. Saerens, S.M.G.; Delvaux, F.R.; Verstrepen, K.J.; Thevelein, J.M. Production and biological function of volatile esters in Saccharomyces cerevisiae. Microb. Biotechnol. 2010, 3, 165-177. [CrossRef] [PubMed]

42. Elías, L.G. Chemical composition of coffee-berry by-products. In Coffee Pulp: Composition, Technology, and Utilization; Braham, J.E., Bressani, R., Eds.; IDRC: Ottawa, ON, Canada, 1979; pp. 11-16.

43. Toci, A.T.; Farah, A. Volatile fingerprint of Brazilian defective coffee seeds: Corroboration of potential marker compounds and identification of new low quality indicators. Food Chem. 2014, 153, 298-314. [CrossRef] [PubMed]

44. Oestreich-Janzen, S. Chemistry of Coffee. In Comprehensive Natural Products II; Liu, H.-W., Mander, L., Eds.; Elsevier Science: Kindlington, UK, 2013; Volume 3, pp. 1085-1117.

45. Toledo, P.R.A.B.; Pezza, L.; Pezza, H.R.; Toci, A.T. Relationship between the different aspects related to coffee quality and their volatile compounds. Compr. Rev. Food Sci. Food Saf. 2016, 15, 705-719. [CrossRef]

46. Gonzalez-Rios, O.; Suarez-Quiroz, M.L.; Boulanger, R.; Barel, M.; Guyot, B.; Guiraud, J.P.; Schorr-Galindo, S. Impact of "ecological" post-harvest processing on the volatile fraction of coffee beans: I. Green coffee. J. Food Compos. Anal. 2007, 20, 289-296. [CrossRef]

47. Akiyama, M.; Murakami, K.; Hirano, Y.; Ikeda, M.; Iwatsuki, K.; Wada, A.; Tokuno, K.; Onishi, M.; Iwabuchi, H. Characterization of headspace aroma compounds of freshly brewed arabica coffees and studies on a characteristic aroma compound of Ethiopian coffee. J. Food Sci. 2008, 73, C335-C346. [CrossRef]

48. Lee, L.W.; Cheong, M.W.; Curran, P.; Yu, B.; Liu, S.Q. Modulation of coffee aroma via the fermentation of green coffee beans with Rhizopus oligosporus: II. Effects of different roast levels. Food Chem. 2016, 211, 925-936. [CrossRef]

49. Afriliana, A.; Pratiwi, D.; Giyarto; Belgis, M.; Harada, H.; Yushiharu, M.; Taizo, M. Volatile compounds change in unfermented Robusta coffee by re-fermentation using commercial kefir. Nutr. Food Sci. Int. J. 2019, 8, 555745. [CrossRef]

50. Peñuela-Martínez, A.E.; Zapata-Zapata, A.D.; Durango-Restrepo, D.L. Performance of different fermentation methods and the effect on coffee quality (Coffea arabica L.). Coffee Sci. 2018, 13, 465-476. [CrossRef] 
51. Mendes-Ferreira, A.; Barbosa, C.; Falco, V.; Leão, C.; Mendes-Faia, A. The production of hydrogen sulphide and other aroma compounds by wine strains of Saccharomyces cerevisiae in synthetic media with different nitrogen concentrations. J. Ind. Microbiol. Biotechnol. 2009, 36, 571-583. [CrossRef] [PubMed]

52. Yvon, M.; Rijnen, L. Cheese flavour formation by amino acid catabolism. Int. Dairy J. 2001, 11, $185-201$. [CrossRef]

53. Plessas, S.; Bekatorou, A.; Gallanagh, J.; Nigam, P.; Koutinas, A.A.; Psarianos, C. Evolution of aroma volatiles during storage of sourdough breads made by mixed cultures of Kluyveromyces marxianus and Lactobacillus delbrueckii ssp. bulgaricus or Lactobacillus helveticus. Food Chem. 2008, 107, 883-889. [CrossRef]

54. Patrignani, F.; Chinnici, F.; Serrazanetti, D.I.; Vernocchi, P.; Ndagijimana, M.; Riponi, C.; Lanciotti, R. Production of volatile and sulfur compounds by 10 Saccharomyces cerevisiae strains inoculated in trebbiano must. Front. Microbiol. 2016, 7, 1-11. [CrossRef] [PubMed]

55. Leclercq-Perlat, M.-N.; Corrieu, G.; Spinnler, H.-E. Comparison of volatile compounds produced in model cheese medium deacidified by Debaryomyces hansenii or Kluyveromyces marxianus. J. Dairy Sci. 2010, 87, 1545-1550. [CrossRef]

(C) 2019 by the authors. Licensee MDPI, Basel, Switzerland. This article is an open access article distributed under the terms and conditions of the Creative Commons Attribution (CC BY) license (http://creativecommons.org/licenses/by/4.0/). 